\title{
The New Economics of Prudential Capital Controls: A Research Agenda
}

\begin{abstract}
ANTON KORINEK*
This paper provides an introduction to the new economics of prudential capital controls in emerging economies. This literature is based on the notion that there are externalities associated with financial crises because individual market participants do not internalize their contribution to aggregate financial instability. We describe financial crises as situations in which an emerging economy loses access to international financial markets and experiences a feedback loop in which declining aggregate demand, falling exchange rates and asset prices, and deteriorating balance sheets mutually reinforce each other-a common phenomenon in recent emerging market crises. Individual market participants take aggregate prices and financial conditions as given and do not internalize their contribution to financial instability when they choose their actions. As a result they impose externalities in the form of greater financial instability on each other, and the private financing decisions of individuals are distorted toward excessive risk-taking. Prudential capital controls can induce private agents to internalize their externalities and thereby increase macroeconomic stability and enhance welfare. [JEL F34, F41, E44, H23]
\end{abstract}

IMF Economic Review (2011) 59, 523-561. doi:10.1057/imfer.2011.19

*Anton Korinek is an assistant professor of economics at the University of Maryland. The author would like to thank Julien Bengui, Maya Eden, Martin Evans, Giovanni Favara, Rex Ghosh, Olivier Jeanne, Nicolas Magud, Ha Nguyen, Krisztina Orban, Jonathan Ostry, Roberto Piazza, Carmen Reinhart and Joseph Stiglitz as well as participants of the Inaugural Conference of the Institute for New Economic Thinking and the 2011 IEA Meetings and two anonymous referees for helpful comments and suggestions. The author would also like to acknowledge Carmen Reinhart for sharing data on the relationship between financial liberalization and instability. Work on this project was undertaken while the author was a visiting scholar at the IMF. The views expressed are those of the author and should not be attributed to the IMF. The title of this paper is inspired by the description of the emerging "new theory of prudential capital controls" by Jeanne, Subramanian, and Williamson (2012). 
$E$ merging market economies that are integrated into global capital markets are exposed to boom and bust cycles in international capital flows. During good times, they experience strong capital inflows; in bad times, the flows reverse and often trigger systemic financial crises. Empirical evidence on the relationship between capital market liberalization and financial instability is presented, for example in Reinhart and Rogoff (2009). Figure 1, which is replicated from their work, illustrates this relationship by plotting an index of capital mobility by Obstfeld and Taylor (2003) and the incidence of systemic banking crises over the past two centuries.

The destabilizing patterns of international capital flows in economies that have liberalized their capital markets have imposed severe welfare costs and are hence of grave concern for policymakers and society at large. A number of emerging market economies have recently responded to these concerns by imposing prudential controls on international capital flows. ${ }^{1}$

This paper synthesizes the advances of an active recent literature that finds that prudential controls on capital flows to emerging economies may be desirable from a welfare theoretic perspective because they reduce the incidence and severity of financial crises, which in turn reduces the pecuniary externalities that arise during such crises (Korinek, 2010a). The starting point for this argument is grounded in a well-established literature, which has demonstrated that financial crises in emerging economies can be understood as episodes of financial amplification (see, for example, Krugman, 1999; Aghion, Bacchetta, and Banerjee, 2000; Mendoza, 2002, among many others): when emerging economies experience shocks that lead to a decline in aggregate demand, their exchange rates depreciate and asset prices fall. This results in adverse balance sheet effects, that is a declining value of collateral and net worth. In the presence of financial market imperfections, such balance sheet effects constrain the access of economic agents to external finance, which in turn forces them to cut back on their spending and contract aggregate demand further, as illustrated in Figure 2. As a result of this feedback loop, economic shocks may have amplified effects on macroeconomic aggregates, as is captured by the notion of financial amplification. In the following, we will employ the term "financial crisis" as synonymous with financial amplification. ${ }^{2}$

The new literature on prudential capital controls analyzes the normative side of this mechanism and finds that the falling exchange rates and asset prices that drive financial amplification effects lead to pecuniary externalities that result in distortions of the financing and investment decisions of private market participants. Small market participants rationally take exchange rates

\footnotetext{
${ }^{1}$ For example, from 2009 to 2011, the countries that have imposed new regulations or extended existing prudential regulations on capital inflows include Brazil, Colombia, Indonesia, Korea, Taiwan, Thailand and Peru. See Ostry and others (2011).

${ }^{2}$ The literature employs several different terms for this basic mechanism, including debt deflation, Fisherian deflation, or financial accelerator.
} 
Figure 1. Capital Mobility and Financial Fragility

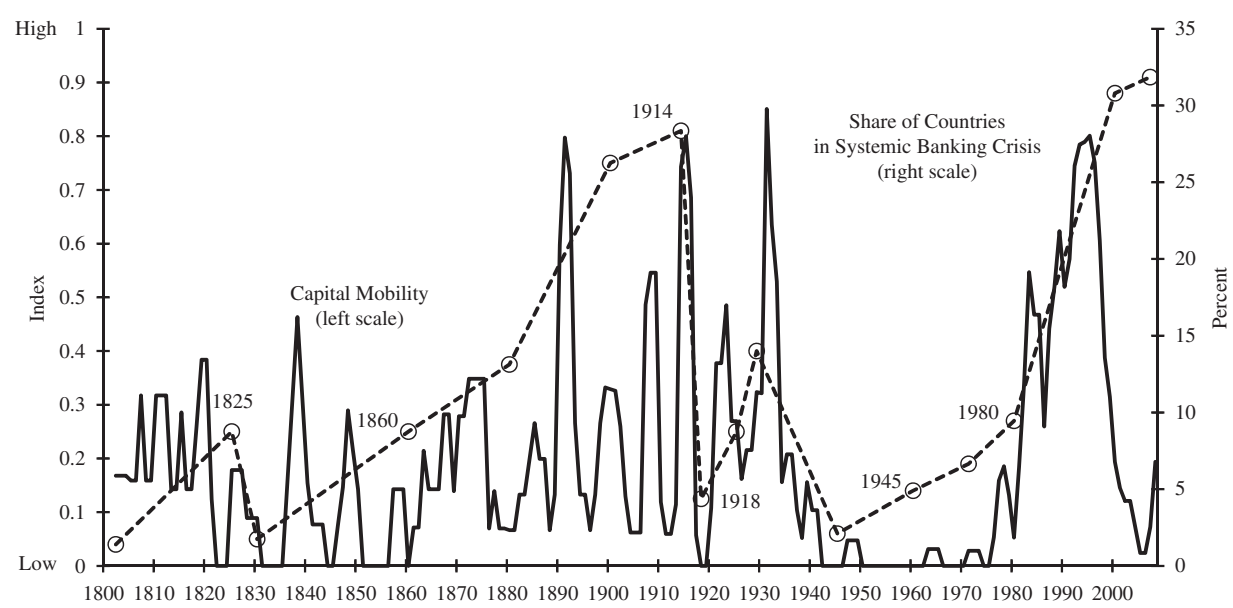

Notes: Episodes of high capital mobility (dashed line) have historically been associated with a greater incidence of financial crises (solid line). See Reinhart and Rogoff (2009).

Figure 2. Financial Amplification Effects

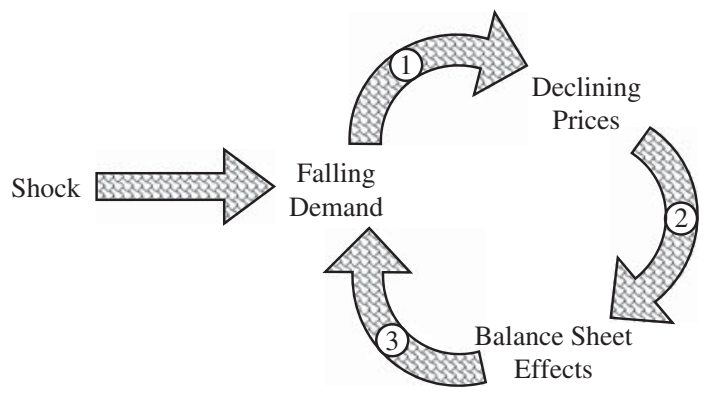

Notes: Financial amplification effects are characterized by a feedback loop of (1) declining exchange rates and asset prices, (2) adverse balance sheet effects, and (3) falling aggregate demand.

and asset prices as given, since they are determined by aggregate economic conditions. In aggregate, however, their joint behavior determines the level of exchange rates and asset prices, and by implication the extent of balance sheet effects and the degree of financial fragility in the economy. Private market participants neglect the price effects of their actions and the resulting balance sheet effects, which represent pecuniary externalities. As a result, they fail to internalize their contribution to financial amplification.

These externalities introduce distortions in a wide range of financing decisions of emerging market agents. In particular, they induce private market participants to raise too much debt, to take on excessively risky forms of finance, for example foreign currency debt rather than FDI, and to borrow 
at excessively short maturities. As a result of their distorted incentives, the economy suffers from an excessive level of financial fragility.

In a sense, financial fragility is an uninternalized by-product of external financing, just as air pollution is an uninternalized by-product of driving. It is privately optimal for drivers to enjoy the benefits of their mobility while disregarding the pollution that they impose on the rest of society, since each driver knows that her individual contribution to air pollution is minuscule. In aggregate, however, there will be excessive pollution if all drivers act accordingly. In other words, clean air is a public good and will be subject to a "tragedy of the commons" in the free market equilibrium. This presents a textbook policy case: if we make drivers internalize the pollution that they create, for example by imposing Pigouvian taxes or regulations, the decentralized market equilibrium will be efficient.

In a similar manner, external financing "pollutes" emerging economies with financial fragility - it makes them more fragile and reinforces the financial amplification effects that arise in response to adverse shocks. Private agents do not internalize this - they take the aggregate level of financial fragility as given, even though they jointly determine the fragility of the economy. Just as in the case of air pollution, Pigouvian taxes or regulations on external financing in emerging economies align the private and social costs of financing decisions and restore the efficiency of the decentralized market equilibrium. Such policy measures can therefore make everybody in the economy better off.

The critical reader may wonder why the depreciations in exchange rates and asset prices that occur during financial amplification effects are associated with economic distortions, although price adjustments in normal times are viewed as part of the optimal adjustment mechanism to shocks. For example, every microeconomics textbook tells us that it is efficient to let oil prices adjust in response to a supply shock, and that attempts to slow the adjustment through subsidies will introduce distortions in both the demand and supply of oil, thereby reducing welfare. The fundamental distinction between the two cases is that in the textbook example about oil prices, the market is assumed to be complete and unconstrained. By contrast, financial amplification effects occur only when financial markets are imperfect and constrained by balance sheet effects.

Before proceeding, let us delineate the scope of this article. First, our focus is on prudential capital controls that correct the economy-wide incentives for excessive risk-taking of emerging market agents. The term prudential captures that we refer to capital controls that are imposed to stem the buildup of risk before a financial crises materializes. (We touch upon the benefits of prudential capital controls vs. ex-post policy interventions that are employed once a financial crisis hits in an extension in section 'Prudential Capital Controls vs. Ex-Post Intervention'.) We do not cover capital controls on outflows or capital controls that are for other than prudential motives. See, for example, Neely (1999) for an overview of nonprudential motives to impose capital controls. Furthermore, we focus on welfare-maximizing 
prudential capital controls and do not consider political economy distortions that may lead governments to impose capital controls (see, for example, Tirole, 2003). We also exclude issues of time consistency, such as those studied as a rationale for prudential regulation in Fahri and Tirole (2011).

Secondly, we focus on prudential capital controls rather than other forms of macroprudential regulation. The two are closely related, both in their objective and in the modeling approaches that are used to motivate such regulation. The defining feature of capital controls is that they discriminate based on the residency of investors. This is desirable because international investors who withdraw funds in a financial crisis give rise to a transfer problem - any capital outflow puts further pressure on the exchange rate and causes further pecuniary externalities through the resulting exchange rate movement. International investors care more about the level of the exchange rate than domestic investors who consume goods denominated in the domestic consumption basket. This creates a role for discriminating regulations based on residency, that is for imposing prudential capital controls rather than other macroprudential regulations. See Borio (2011) for a recent survey of the literature on macroprudential regulation in closed economies and Jeanne and Korinek (2010b) for an example.

Thirdly, we limit our survey to the theoretical literature on prudential capital controls. There is also a vast empirical literature on the topic. Since prudential capital controls are usually imposed at times when capital inflows are large, this literature has to solve a difficult endogeneity problem. See, for example, Magud, Reinhart, and Rogoff (2011) for a detailed survey.

Finally, let us discuss the relationship between Tobin taxes and the new literature on prudential capital controls. Tobin (1978) argues that price movements in international financial markets occur at such a rapid pace that real factors such as capital and labor cannot keep up, leading to painful episodes of adjustment in the real economy. He advocates "to throw some sand in the wheels of our excessively efficient international money markets" by imposing a small tax on foreign exchange transactions that aims to reduce the volume of transactions. By contrast, the new literature on prudential capital controls analyzes a specific externality, which allows us to design capital controls that precisely address the underlying market imperfection, to conduct a clean welfare analysis, and to quantify optimal policy measures. In this new literature, the proposed tax is to be levied on the stock of outstanding financial liabilities to reduce the aggregate risk exposure of a country, rather than on the flow to reduce the volume and speed of transactions.

The rest of the paper is organized as follows: In the ensuing section, we discuss a brief history of models of financial crises and how they relate to evolving views of the desirability of capital controls. Then we develop a benchmark model of financial amplification and discuss in detail the role that is played by balance sheet effects. Section III shows that private agents undervalue the cost of financial liabilities during episodes of financial amplification, and section IV discusses a wide range of implications for the 
financing decisions in an unregulated emerging economy, including excessive borrowing, excessive risk-taking, and excessive short-term debt. This section presents a detailed analysis of the recent literature on the externalities of financial crises and capital controls. Section V covers a number of additional questions that are discussed in this emerging literature. These include the desirability of ex-ante prudential capital controls vs. ex-post policy interventions to mitigate the effects of financial crises, the relationship between capital controls, investment and economic growth, the effects of global interest rates on the desirability of capital flow regulation, and the effects of capital controls in a multicountry setting.

\section{Models of Financial Crises}

\section{A Brief History}

Traditional models of crises in emerging economies laid the blame for financial instability on distorted government policies. The literature on currency crises is typically distinguished into three "generations" (see, for example, Burnside, Eichenbaum, and Rebelo, 2008). In "first-generation" models of crises such as Krugman (1979) and Flood and Garber (1984), a profligate government relied excessively on seigniorage revenues and, at some point, had printed so much money that an existing exchange rate peg was no longer sustainable and devaluation was inevitable. Such models largely captured the dynamics experienced by Latin American countries during the 1970s and 1980s. "Second-generation" models of financial crises, such as Obstfeld (1994), were developed after the collapse of the European Exchange Rate Mechanism in 1992/3 and described devaluations as a multiple equilibrium phenomenon: if defending an exchange rate peg carried large social costs in terms of contractionary macroeconomic policies, and if government therefore could not commit to defending a peg, speculation could force a devaluation of the exchange rate. Early "third-generation" models of crises such as McKinnon and Pill (1998) and Krugman (2001) argued that governmental bailout guarantees invited emerging market borrowers to take on excessive risk and therefore exposed their country to the possibility of crisis.

In all these models, free capital flows were not at fault for the ensuing crises: instead, the clear implication was that government should fix its distorted policies so that emerging economies would no longer experience crises and could enjoy the full benefits of international financial integration, that is access to foreign finance to augment their capital stock and to engage in international risk-sharing.

The East Asian crisis in 1997/98 forced a rethink: Policy distortions did not seem to be at the center stage of the fierce declines in exchange rates, credit and economic activity that characterized these crises. (This is not to say that the countries involved did not have their fair share of policy distortions - crises always have the property of shining light on the weak spots in a country's governance.) Instead, it seemed that a crucial factor in 
the East Asian crises were severe balance sheet effects that magnified the impact of fundamental shocks and policy distortions. In the presence of short-term foreign-currency-denominated debts, a relatively small shock, possibly a mild slowdown in productivity, led to a self-reinforcing cycle of declining exchange rates and asset prices, deteriorating balance sheets, and contracting economic activity.

Economists soon developed formal models of the mechanics of financial amplification involving balance sheet effects (see, for example, Krugman, 1999; Aghion, Bacchetta, and Banerjee, 2000), and such balance sheet effects were viewed as a crucial factor in explaining the dynamics of emerging market crises (see, for example, Frankel, 2005; Burnside, Eichenbaum, and Rebelo, 2008). However, most mainstream economists continued to believe in the desirability of free capital flows. What was at first little noticed was that models of balance sheet effects and financial amplification generically involve pecuniary externalities that imply that free capital flows are inefficient, as we will discuss in greater depth in the following sections.

\section{Balance Sheet Effects and Financial Amplification}

Financial amplification effects arise when an economy experiences a selfreinforcing feedback loop of declining exchange rates and asset prices, deteriorating balance sheets, and contracting economic activity. We illustrate this feedback loop in Figure 2 and discuss each of the three elements in detail:

1. Declining prices: Large adverse shocks to aggregate demand in emerging economies typically lead to exchange rate depreciations and declining asset prices. This is both an empirical regularity and a feature of a wide range of models of exchange rate and asset price determination.

Exchange rates may depreciate for a number of reasons: In real models without money, depreciations switch expenditure from foreign goods toward domestic goods to re-equilibrate the economy, as, for example, in Krugman (1999) or Mendoza (2002). In standard monetary models with passive monetary policy (such as Mundell-Fleming), declines in aggregate demand reduce money demand and therefore depreciate the exchange rate, as in Aghion, Bacchetta, and Banerjee (2001). In models of active monetary policy, domestic demand shocks are countered with declines in domestic interest rates so as to soften the impact of the shock, with the effect of depreciating the currency. In fiscal models of the exchange rate, lower aggregate demand implies lower tax revenue and greater need for seigniorage, leading to depreciations, as in the currency crisis model of Burnside, Eichenbaum, and Rebelo (2001). For a detailed discussion of alternative models of exchange rate determination, see Végh (2012).

Asset prices declines may arise from two sources. First, they may be caused by changes in the intertemporal marginal rate of substitution of 
domestic agents - if they are constrained today, they value future payoffs comparatively less and asset prices declines (see, for example, Jeanne and Korinek, 2010a, b). Secondly, if domestic agents cut back on investment, then there is less demand for productive assets. If assets cannot be costlessly transformed into consumption goods, this reduces their relative price according to the q-theory of investment (see, for example, Mendoza, 2010).

2. Balance sheet effects: Exchange rate depreciations and declines in asset prices reduce the collateral and net worth of domestic agents, which in turn reduces their access to credit. The channels through which such credit market imperfections play out are complex and manifold - as in Leo Tolstoy's famous quote, perfect credit markets are all alike; every imperfect credit market is imperfect in its own way.

The literature on financial amplification typically models credit market imperfections as either borrowing constraints or credit spreads. A wide range of models for borrowing constraints have been developed. We discuss specific examples from the literature on financial amplification in the section 'Financial Constraint', in which we introduce the financial constraint in our sample economy. Models of endogenous credit spreads, such as Gertler, Gilchrist, and Natalucci (2007), are typically built on the costly state verification setup of Townsend (1979) and capture that lower net worth leads to a higher probability of bankruptcy and higher expected bankruptcy costs, which are reflected in the spread.

If domestic agents have borrowed in foreign currency, they suffer adverse valuation effects: the domestic value of their debts rises in parallel with the exchange rate depreciation, creating further losses and deterioration in balance sheets (see, for example, Krugman, 1999).

3. Falling aggregate demand: The reduced access to credit tightens the budget constraint of domestic agents and forces them to cut back on consumption and investment. This lowers aggregate demand in the economy, including demand for domestic goods and domestic assets, which feeds back to the price declines that represent the first element of the feedback loop.

The contractionary effects on aggregate demand lead to further depreciations, declines in credit, and so forth, as shown in the figure. Exogenous shocks to the system may therefore be amplified and lead to large effects on aggregate demand, exchange rates and asset prices, as well as credit intermediation.

The initial trigger for amplification effects may be a shock to any of the three elements in the feedback loop: an exogenous shock to exchange rates and asset prices, to balance sheets, or to aggregate demand. An exogenous shock to the exchange rate or to asset prices may be triggered by capital outflows or by an increase in global risk aversion. An exogenous shock to the health of domestic balance sheets may be caused by unexpected losses on the 
capital stock that is held by domestic agents or tighter credit conditions. Adverse shocks to aggregate demand may be caused for example by an exogenous decline in exports or a fall in the growth rate.

When an economy is subject to financial amplification, capital flows become procyclical as constraints on credit are relaxed in good times and tightened in bad times. In other words, countries can least attract finance when they most need it to smooth over temporary negative shocks, and obtain the most credit in good times when they don't need it - capital flows become a destabilizing force, in contrast to the predictions in a frictionless economy. The self-stabilizing forces of the market economy are greatly diminished because exchange rate depreciations and asset price declineswhich are supposed to reequilibrate the market - have the perverse side effect of deteriorating balance sheets and reducing the credit worthiness of borrowers. For every three steps forward that the price movement makes in restoring market equilibrium, the economy slips two steps backward because of adverse balance sheet effects. This implies that prices have to move much strongly than they would in the absence of balance sheet effects, leading to overshooting.

Financial amplification effects that involve falling asset prices are also frequently invoked as a mechanism to describe financial crises in closed economy models (see, for example, Fisher, 1933; Bernanke and Gertler, 1989; Carlstrom and Fuerst, 1997; Kiyotaki and Moore, 1997). The literature on financial amplification in open and closed economies has developed in parallel for close to a century. ${ }^{3}$ There are many commonalities between the two approaches and many authors that contribute to both areas. The main distinction is that only open economy models can explicitly account for the role of the exchange rate in causing balance sheet effects. Empirical evidence suggests that exchange rate depreciations play a crucial role in creating balance sheet effects during crises in small open economies, and that emerging economies are particularly vulnerable to such crises (Frankel, 2005).

\section{A Simple Model of Financial Amplification}

\section{Model Setup}

Let us develop a stylized model of balance sheet effects and financial amplification via exchange rate depreciations based on Korinek (2007, 2010a). This model allows us to analytically illustrate our arguments. We describe the dynamics of financial amplification effects during financial crises and discuss how they differ from the standard functioning of a frictionless market economy.

${ }^{3}$ See, for example, the description of the transfer problem in the open economy by Keynes (1929) and of debt deflation in the closed economy by Fisher (1933). 
Assume a small open endowment economy with two time periods $t=1$ and 2. There are two goods in the first period, a tradable and a nontradable, and the relative price of the nontradable is denoted by $p$, which constitutes a measure of the real exchange rate. For simplicity suppose that there are only tradable goods in the second period. The economy is inhabited by a representative agent with utility function

$$
U=\log \left(c_{1}\right)+c_{T, 2} \quad \text { where } \quad c_{1}=\left(c_{T, 1}\right)^{\sigma}\left(c_{N, 1}\right)^{1-\sigma} .
$$

The variable $c_{1}$ is a consumption index that combines tradable consumption $c_{T, 1}$ and nontradable consumption $c_{N, 1}$ in Cobb-Douglas fashion with expenditure shares $\sigma$ and $1-\sigma$. The consumer obtains endowments of tradable and nontradable goods $\left(y_{T, 1}, y_{N, 1}\right)$ in the first period, which we normalize to $(\sigma, 1-\sigma)$, and an endowment $y_{T, 2}$ of tradable goods in the second period. For simplicity we assume that there is no discounting and that the world gross interest rate is 1 .

The consumer enters period 1 with his endowment and with an inherited amount of tradable debt $d_{0}$, which we assume is subject to an exogenous random shock. (Later we will endogenize the consumer's choice of $d_{0}$.) We denote the consumer's net holdings of tradable goods at the beginning of period 1 by $m=y_{T, 1}-d_{0}$. In period 1 , he chooses how much tradable debt $d_{1}$ to carry into the following period. Given the relative price of nontradable goods $p$, the budget constraints of the consumer are

$$
\begin{aligned}
& c_{T, 1}+p c_{N, 1}=m+p y_{N, 1}+d_{1}, \\
& c_{T, 2}+d_{1}=y_{T, 2} .
\end{aligned}
$$

\section{Financial Constraint}

In order to introduce the possibility of financial amplification effects into our model, we reproduce the assumption of Mendoza (2002) and Korinek (2007, 2010a) that period 1 borrowing is constrained by a fraction $\kappa<\sigma / 1-\sigma$ of the income of the representative agent,

$$
d_{1} \leq \kappa\left(y_{T, 1}+p y_{N, 1}\right) .
$$

A potential microfoundation for this constraint is the following: Assume that consumers may threaten default after taking on their debts and that they can renegotiate their debts at the end of period 1 . If they default, international lenders can seize at most a fraction $\kappa$ of the income of consumers in that period, convert all nontradable goods into tradable goods at the prevailing market price $p$, and repatriate what they receive. ${ }^{4}$ If consumers have all the

\footnotetext{
${ }^{4}$ More generally, we could distinguish between the fraction $\kappa_{T}$ of tradable goods and $\kappa_{N}$ of nontradable goods that lenders can seize. As long as both are positive, our results would continue to hold.
} 
bargaining power, they could renegotiate their debt down to the level indicated by the constraint, and lenders would not be willing to lend more than this level. We can interpret $y_{T, 1}+p y_{N, 1}$ as the international collateral of domestic borrowers. A decline in the exchange rate $p$ reduces the international collateral and by implication the borrowing capacity of domestic consumers, which captures the notion of balance sheet effects in our model.

Observe that nontradable income or assets are a natural part of the collateral in international borrowing and lending relationships between private agents. Although international lenders cannot export nontradable goods, they can seize them in the domestic court system and sell them against tradable goods at the prevailing market price $p$. For example, real estate has played an important role as collateral during many capital inflow booms and busts. ${ }^{5}$

At a more general level, the constraint represents the notion that higher income and net worth reduce the agency problems that exist between borrowers and lenders and therefore allows for more lending, for example by providing more seizable collateral.

Although there is a large number of specifications of financial market imperfections, not every specification leads to financial amplification effects. A crucial ingredient to obtain such effects is a relative price-such as an exchange rate, an asset price, or an interest rate-which moves in a direction that hurts constrained agents when an adverse shock occurs. This may happen either because the relative price movement directly tightens their financial constraints, as in our analytic illustration, or because it leads to negative income and wealth effects on constrained agents. Let us discuss each of these two categories in turn.

Models in the first category feature a financial constraint that directly depends on a relative price. For example, the borrowing constraint in our specification (4) is based on current income and the current exchange rate. This captures the notion that current income plays an important role in the current incentives of borrowers and reflects common practice in a number of credit markets, such as those for mortgages. Alternatively, the borrowing constraint may depend on the future collateral of borrowers at the time of repayment, as for example in Céspedes, Chang, and Velasco (2011) or in the appendix of Korinek (2010a). ${ }^{6}$ Two similar categories of constraints exist in the literature on financial amplification and asset prices: Jeanne and Korinek (2010b) and Mendoza (2010) impose a financial constraint that depends on

${ }^{5}$ There is an instructive analogy to asset markets: a lender who lends to an airline company that uses planes as a collateral has no intrinsic use for planes. In the event of default the lender seizes the planes and sells them to other airlines against cash.

${ }^{6}$ In models of financial amplification in which the borrowing constraint depends on future prices, it is necessary to introduce investment as a link between the current period and the future. Amplification arises when borrowing constraints at time $t$ become binding, which reduce investment at time $t$ and lower income and prices at time $t+1$, which in turn reduces borrowing at time $t$ further, and so on. 
current asset prices, whereas Kiyotaki and Moore (1997) imposes a constraint that depends on future asset prices and collateral. ${ }^{7}$

Models in the second category feature a relative price that leads to income or wealth effects. Financial amplification occurs when a shock leads to a change in relative prices that imposes a negative income or wealth effect on those agents who experienced the shock. For example, Krugman (1999), Aghion, Bacchetta, and Banerjee (2001) and Schneider and Tornell (2004) specify a borrowing constraint in which emerging market agents can take on debt up to a multiple of their net worth, and net worth is affected by exchange rate depreciations. Caballero and Krishnamurthy (2001, 2004) describe a framework of emerging economies in which constraints in international and domestic credit markets interact and lead to inefficiencies of the type of Bhattacharya and Gale (1987) and Jacklin (1987): the lower the availability of dollar liquidity in the emerging economy, the higher domestic interest rates, which makes distressed borrowers poorer and reinforces the adverse shock, capturing a form of amplification. Lorenzoni (2008) assumes that entrepreneurs can only pledge a fraction of their future earnings. When they are borrowing constrained, fire sales lead to asset price declines that make them poorer, which constitutes a form of financial amplification. In all these specifications, there is a relative price movement that does not enter financial constraints directly but that leads to negative income or wealth effects that reinforce an initial shock.

Empirical studies of financial amplification effects attempt to identify the price effects through which negative shocks to one agent have an adverse impact on other agents in the same sector (see for example Benmelech and Bergman, 2011). This is complicated by the fact that many shocks affect the sector as a whole. Given the similarity of the different specifications of financial constraints, the economic literature has not yet found a way to empirically disentagle which ones best reflect the data.

\section{Model Solution}

We express the optimization problem of the consumer as a function of the economy's period 1 holdings of tradable goods $m=y_{T, 1}-d_{0}$, which depends on the shock to $d_{0}$, and tradable endowment $y_{T, 1},{ }^{8}$

$$
V\left(m ; y_{T, 1}\right)=\max \log \left(c_{T, 1}\right)^{\sigma}\left(c_{N, 1}\right)^{1-\sigma}+c_{T, 2} \quad \text { s.t. } \quad(2),(3) \text { and (4). }
$$

Equilibrium in the economy is characterized by a set of allocations $\left(c_{T, 1}, c_{N, 1}, d_{1}, c_{T, 2}\right)$ and a price $p$ such that this maximization problem is

\footnotetext{
${ }^{7}$ However, Kocherlakota (2000) and Cordoba and Ripoll (2004) caution that the constraint specification of Kiyotaki and Moore (1997) does not yield quantitatively large amplification effects in calibrated models.

${ }^{8} \mathrm{We}$ include $y_{T, 1}$ as a separate argument to the function $V(\cdot)$ since it shows up not only in the budget constraint (where it is captured by the variable $m$ ) but also in the borrowing constraint.
} 
solved and markets clear, that is, $c_{N, 1}=y_{N, 1}=1-\sigma$ for nontradable goods and $c_{T, 1}=m+d_{1}$ for tradable goods. Assigning the shadow prices $\mu$ and $\lambda$ to the period 1 budget constraint and borrowing constraint, the first-order conditions of the consumer are

$$
\begin{array}{ll}
\operatorname{FOC}\left(c_{T, 1}\right): & \frac{\sigma}{c_{T, 1}}=\mu, \\
\operatorname{FOC}\left(c_{N, 1}\right): & \frac{1-\sigma}{c_{N, 1}}=\mu p, \\
\operatorname{FOC}\left(d_{1}\right): & 1+\lambda=\mu .
\end{array}
$$

Combining the first two optimality conditions and imposing domestic market clearing for nontradable goods, we obtain

$$
p=\frac{c_{T, 1}}{\sigma}
$$

The real exchange rate is an increasing function of tradable consumption, which we can loosely interpret as a measure of aggregate demand in period 1. (The response of the exchange rate corresponds to element 1 in the feedback cycle of financial amplification in Figure 2.) In our model, the consumer wants to spend fixed shares of his consumption on tradable and nontradable goods, given the Cobb-Douglas utility function. Since the quantity of nontradable goods in the economy is constant, any increase in tradable consumption needs to be matched by a parallel increase in the price of nontradable goods to keep the expenditure shares on the two goods constant and to ensure that the market for nontradable goods clears.

Loose financial constraints: For sufficiently low levels of initial debt $d_{0}$ the financial constraint on the representative consumer will be loose so $\lambda=0$ and $\mu=1$. Then the consumer chooses to consume $c_{T, 1}=\sigma=y_{T, 1}$ and borrow $d_{1}=d_{0}$, and the exchange rate is $p=1$. This allocation satisfies the borrowing constraint if $d_{0} \leq \kappa$. For unconstrained levels of initial debt, the economy therefore achieves the first-best allocation, which we denote by $f b$.

We substitute these allocations in equation (5) to express the utility of the consumer in the first-best allocation as a function of the economy's period 1 holdings of tradable goods $m$ and $y_{T, 1}$.

$$
V^{f b}\left(m ; y_{T, 1}\right)=v^{f b}+m
$$

for an appropriate constant $v^{f b}$. The derivative of this function with respect to $m$ captures the marginal valuation of holding liquid tradable goods (in short: marginal value of liquidity), which we denote by

$$
V_{m}^{f b}(\cdot)=1
$$


Binding financial constraints: If $d_{0}>\kappa$, then the financial constraint on the consumer is binding and determines the level of borrowing and tradable consumption

$$
\begin{aligned}
& d_{1}=\kappa\left[y_{T, 1}+p y_{N, 1}\right], \\
& c_{T, 1}=m+d_{1} .
\end{aligned}
$$

Equation (7) captures element 2 in the feedback cycle of financial amplification in Figure 2, since a lower exchange rate reduces how much individual agents can borrow. Equation (8) captures element 3 in the feedback cycle, since lower borrowing $d_{1}$ reduces the consumption of domestic agents.

The constrained consumer with $d_{0}>\kappa$ recognizes that his utility, given period 1 liquid tradable resources $m=y_{T, 1}-d_{0}$, is

$$
V^{c o n}\left(m ; y_{T, 1}\right)=v^{c o n}+\sigma \log \left\{m+d_{1}\right\}-d_{1}
$$

for an appropriate constant $v^{c o n}$. The consumer's marginal value of liquidity under binding constraints is

$$
V_{m}^{c o n}(\cdot)=\frac{\sigma}{c_{T, 1}} .
$$

Since $c_{T, 1}<\sigma$ under binding constraints, observe that $V_{m}^{c o n}>V_{m}^{f b}$ - the marginal value of liquidity is higher (and, conversely, debt repayments are more costly) when the constraint is binding than when it is loose.

In general equilibrium, the real exchange rate is given by $p=c_{T, 1} / \sigma$, which implies

$$
d_{1}=\kappa\left[y_{T, 1}+y_{N, 1} \cdot \frac{c_{T, 1}}{\sigma}\right] .
$$

Solving the two equations (8) and (10) in $c_{T, 1}$ and $d_{1}$, we obtain

$$
\begin{aligned}
& d_{1}=\kappa \cdot \frac{\sigma y_{T, 1}+m y_{N, 1}}{\sigma-\kappa y_{N, 1}}, \\
& c_{T, 1}=\sigma \cdot \frac{m+\kappa y_{T, 1}}{\sigma-\kappa y_{N, 1}} .
\end{aligned}
$$

Since $d_{0}>\kappa$, the fractions in both terms are less than 1 ; therefore the constrained levels of borrowing $d_{1}$ and consumption $c_{T, 1}$ are less than the unconstrained levels, which were given by $d_{0}>\kappa$ and $\sigma$ respectively.

When borrowing constraints are binding, our model exhibits financial amplification. Assume a shock that leads to a marginal change in the initial 
level of debt and therefore a change $d m$ in the liquid tradable resources of the consumer. The response of tradable consumption is

$$
\frac{d c_{T, 1}}{d m}=\frac{\sigma}{\sigma-\kappa y_{N, 1}}>1 .
$$

An increase in $m$ leads to an amplified increase in consumption. This occurs because higher liquid wealth $m$ leads to higher tradable consumption $c_{T, 1}$, which appreciates the real exchange rate $p$ and relaxes the borrowing constraint on the consumer, and so forth (see Figure 2).

\section{Financial Amplification and Pecuniary Externalities}

The preceding section has highlighted the central role played by exchange rate depreciations and asset price declines during episodes of financial amplification. In this section, we emphasize that these price movements entail pecuniary externalities.

We start with a general definition of externalities and distinguish them into pecuniary externalities and technological externalities. Next we discuss under what conditions pecuniary externalities are consistent with Pareto efficiency and when they lead to economic distortions that call for policy intervention. We formalize our insights in the context of the analytical model of financial amplification that we developed in the preceding section. Finally, we discuss the implications for the efficiency of capital inflows in emerging economies and the desirability of prudential capital controls.

\section{Pecuniary Externalities and Efficiency}

Externalities are defined as indirect effects of an economic activity on agents other than the originators of such activity (see, for example, Laffont, 1987). We distinguish externalities into technological externalities and pecuniary externalities. Technological externalities arise when an economic activity has direct effects on the utility function or the production function of another agent who is not involved in the activity. The textbook example of a technological externality is pollution-car drivers enjoy the benefits of driving but produce pollution as a by-product, which reduces the utility of other agents in the economy who are not involved in the driving activity.

Pecuniary externalities, by contrast, arise when an economic activity affects relative prices and this has an indirect effect on the welfare of another agent by changing her consumption set or her production set. In other words, pecuniary externalities work through the price system. To reproduce a typical example, provided by Laffont (1987): if one person consumes more whiskey and raises the price of whiskey, this increases the welfare of whiskey producers and decreases the welfare of whiskey consumers, imposing positive and negative pecuniary externalities on them.

In an economy with complete markets and price taking behavior, the first fundamental theorem of welfare economics states that the decentralized 
equilibrium is Pareto efficient in spite of such pecuniary externalities. ${ }^{9}$ Relative prices reflect the relative marginal utilities of all goods for all agents, so that nobody has an incentive to engage in further transactions. If a relative price changes, the resulting pecuniary externalities "net out" since the gains experienced by the sellers of a good are precisely offset by the losses suffered by the buyers of the good. The new equilibrium is still Pareto efficient - no agent in the economy can be made better off without hurting the welfare of another agent.

The observation that pecuniary externalities are consistent with Pareto efficiency under the conditions of the first welfare theorem has led some economists to argue that they are not really externalities and should not be called externalities. However, the term is useful for welfare analysis in an environment of incomplete markets, such as the one we describe in this paper. In accordance with the literature on the inefficiencies that arise under incomplete markets (see for example Greenwald and Stiglitz, 1986), we use the term "pecuniary externalities" for any indirect welfare effects that one agent imposes an another through the price system, no matter whether the market is complete or not.

Given this definition, pecuniary externalities are part of the normal functioning of a market economy. They occur whenever an agent changes his demand or supply of a good and prices move to correctly reflect the relative scarcity of resources in the economy. In consumer theory, what we term pecuniary externalities corresponds to the income and wealth effects of price changes, which, together with substitution effects, represent the mechanism through which the invisible hand equilibrates the market.

On the other hand, pecuniary externalities are associated with inefficiencies when the conditions of the first welfare theorem are violated, that is when agents do not behave competitively or when markets are incomplete. When agents do not behave competitively and exert pricing power, they recognize that reducing their demand (supply) will manipulate relative prices and entail pecuniary externalities that go in their favor. In the resulting equilibrium it is well known that the quantity transacted is inefficiently low and there is a monopoly wedge between the marginal valuations of buyers and sellers of goods. Because of this wedge, both sides of the market would benefit from increasing the quantity transacted.

When markets are incomplete, the market structure prevents individuals from equalizing their marginal utilities for all goods across all time periods and states of nature. In such an environment, price movements entail pecuniary externalities that generally do not cancel out. ${ }^{10}$ The decentralized

\footnotetext{
${ }^{9} \mathrm{An}$ additional technical condition is that the preferences of all agents need to be locally nonsatiated.

${ }^{10}$ There are several special circumstances, however, when equilibrium is constrained efficient even if markets are incomplete. These include economies with a single good (because there are no relative prices that could trigger pecuniary externalities) and economies with a single or representative agent (because there is no trade in such an economy). For a detailed discussion, see Arnott, Greenwald, and Stiglitz (1992).
} 
equilibrium is not constrained Pareto efficient in such a setting because a planner who is subject to the same market incompleteness as private agents can achieve a superior equilibrium: a planner can instruct decentralized agents to deviate from their private optimality conditions at a second-order cost, and these deviations may lead to changes in relative prices and pecuniary externalities that have first-order benefits because they redistribute resources from agents with a lower marginal valuation to those with a higher marginal valuation. ${ }^{11}$

In our analytic example above, the market for borrowing is constrained because borrowing is limited by the value of the borrower's collateral. When the constraint is binding, the effect is similar to that of a market incompleteness: the borrower values resources today relatively more than the lender, and the two agents are prevented from equating their relative marginal utilities. In such an environment pecuniary externalities matter: an appreciation in the exchange rate or an increase in asset prices that raises the value of the borrower's collateral and relaxes the borrowing constraint will allow for more lending. This brings the economy closer to the first-best allocation that would prevail in the absence of the borrowing constraint and constitutes a Pareto improvement.

Externalities can be viewed as a coordination problem: if decentralized agents could coordinate their actions, they would collectively attempt to limit the adverse price movements that damage their balance sheets in crisis states. All agents would be better off, but there is a free-rider problem: every individual agent has incentives to enjoy the benefits resulting from the coordinated behavior of all other agents and implement his private optimum.

\section{Pecuniary Externalities in Open Economy Macroeconomics}

In open economy macroeconomics, the exchange rate plays a crucial stabilizing role when markets are complete. If the domestic economy experiences an adverse shock, equilibrium is restored through a depreciation in the exchange rate. Under normal circumstances, exchange rate depreciations have expansionary (competitiveness-enhancing) effects and therefore play a stabilizing role in the economy. This effect is what led, for example, Friedman (1953) to advocate flexible exchange rates.

A similar argument can be made about the stabilizing role of asset price movements in response to shocks. For example, if resources are scarce because of a temporary adverse shock or if future productivity declines, falling asset prices provide a market signal that it is desirable to reduce investment. Again, asset price movements are the mechanism through which

${ }^{11}$ See Hart (1975), Stiglitz (1982), Geanakoplos and Polemarchakis (1986) and Greenwald and Stiglitz (1986) for a discussion of the inefficiency of the decentralized equilibrium in economies with incomplete markets at a technical level. Arnott, Greenwald, and Stiglitz (1992) provide an excellent intuitive description. 
the invisible hand restores equilibrium in the demand and supply for investment.

Exchange rate and asset price movements lead to pecuniary externalities - for example, in most models of exchange rate determination, a depreciation implies that domestic consumers have to pay more to import foreign goods, which is a negative income effect. As long as markets are complete and unconstrained, the relative marginal utilities of domestic agents and foreigners are equalized. Pecuniary externalities that redistribute between them do not interfere with Pareto efficiency because the negative income effects on domestic agents are precisely offset by positive income effects for foreigners who earn more on their goods.

In an economy that is subject to borrowing constraints, this is no longer the case. Domestic agents value consumption goods relatively more than foreigners - they would be willing to pay a higher interest rate than the market rate if they were allowed to borrow, but the constraint prevents them from doing so. By implication, the negative income effects of exchange rate depreciations on domestic agents are larger than the positive income effects on foreigners, and aggregate welfare is reduced. If exchange rates or asset prices directly enter the borrowing constraint of domestic agents, as in our analytic example, then the relative price movement tightens a binding constraint, which also reduces aggregate welfare. Observe that the negative welfare effects caused by such price movements correspond closely to what we summarized as "balance sheet effects" in our diagram of financial amplification. They are what makes amplification effects and financial crises so costly in terms of welfare.

In the decentralized equilibrium of the economy, domestic agents take all prices, including exchange rates and asset prices, as given. Small agents rationally recognize that their impact on prices is small. ${ }^{12}$ However, if the economy is subject to amplification effects, everybody would be better off if they coordinated to take advantage of their pricing power to counter the effects of relative price movements that are Pareto inefficient. A planner would do precisely that, as we will discuss in the following.

\section{Undervaluation of Liquidity}

We introduce a constrained social planner into our earlier model and compare the allocation chosen by this planner with the decentralized equilibrium. We assume that the planner optimizes the welfare of domestic consumers subject to the same constraints as decentralized consumers, including the borrowing constraint, the budget constraints, and constraints on the market structure. In evaluating the borrowing constraint, the planner

\footnotetext{
${ }^{12}$ Even if some market participants have some market power, they will not fully internalize the social costs of the pecuniary externalities that result from their actions. For example, in a duopoly, each player would find it optimal to internalize only 50 percent of the pecuniary externalities.
} 
internalizes that the exchange rate at which nontradable collateral is valued is determined by the marginal rate of substitution between tradable and nontradable goods, as given by the exchange rate equation (6). ${ }^{13}$

This notion of a constrained planner differs significantly from a first-best planner who would have the power to ignore the borrowing constraints and budget constraints of individual agents. However, constrained planning problems better capture the situation of a regulatory authority in the real world. Since the economy under consideration is small and the planner's actions do not affect the global equilibrium, any welfare improvement in the domestic economy also constitutes a global Pareto improvement.

When the financial constraint in the economy is loose, it is easy to see that both decentralized agents and the constrained planner implement the first-best allocation. In this allocation, they both perceive the marginal value of liquidity as $V_{m}^{f b}=1$. However, this changes when borrowing constraints are binding and financial amplification effects are triggered:

Lemma 1 (Undervaluation of Liquidity) Decentralized agents in an economy that is subject to financial amplification effects undervalue liquidity compared with a constrained planner.

An analogous way of stating the lemma is that decentralized agents undervalue the cost of financial payouts when the constraint is binding.

Proof: Decentralized agents perceive the benefit of a marginal unit of liquidity when the financial constraint is binding as $V_{m}^{c o n}=\sigma / C_{T, 1}$. In taking the derivative of the value function (9), domestic consumers take the borrowing limit $d_{1}$ as given since all the variables on the right-hand side of equation (7) are exogenous for price takers. In general equilibrium, we can substitute for $c_{T, 1}$ from equation (11) to re-write this expression as

$$
V_{m}^{c o n}(\cdot)=\frac{\sigma-\kappa y_{N, 1}}{m+\kappa y_{T, 1}}
$$

A social planner, on the other hand, internalizes that the exchange rate $p$ in (7) is endogenous to the aggregate period 1 tradable resources $m=y_{T}-d_{0}$ in the economy. She recognizes that the borrowing limit $d_{1}$ is given by equation (10) and the value function of consumers is

$$
V^{s p}\left(m ; y_{T, 1}\right)=v^{s p}+\sigma \log \left[m+\kappa y_{T, 1}\right]-\kappa \cdot \frac{\sigma y_{T, 1}+m y_{N, 1}}{\sigma-\kappa y_{N, 1}}
$$

\footnotetext{
${ }^{13}$ This formulation of a constrained planning problem, in which the planner has no other instruments than the decentralized market, is the most basic criterion for Pareto inefficiency. If we give the planner additional instruments, it is natural that she can improve the equilibrium further. See for example the section 'Prudential Capital Controls vs. Ex-Post Intervention' for a discussion of how a planner would use mitigating policy measures once a crisis has occurred.
} 
for an appropriately chosen constant $v^{s p}$. Taking the derivative of the value function with respect to $m$, we obtain the marginal benefit of liquidity as perceived by the social planner:

$$
V_{m}^{s p}(\cdot)=\frac{\sigma}{m+\kappa y_{T, 1}}-\frac{\kappa y_{N, 1}}{\sigma-\kappa y_{N, 1}} .
$$

Comparing the two marginal valuations of liquidity we find

$$
V_{m}^{s p}>V_{m}^{c o n}
$$

(Recall that the constraint binds when $d_{0}>\kappa$ and that we normalized $y_{T, 1}+y_{N, 1}=1$.)

During episodes of financial amplification, decentralized agents only recognize the private benefits of additional liquidity and take the tightness of the financial constraint, as captured by $V_{m}^{\text {con }}$, as given.

By contrast, a constrained social planner coordinates the actions of decentralized agents and internalizes the social benefits of additional liquidity as captured by $V_{m}^{s p}$. She recognizes that additional liquidity $m$ across the economy raises aggregate demand, which appreciates the exchange rate and leads to positive financial amplification effects. We depict the discrepancy between the two valuations of liquidity $V_{m}^{c o n}$ and $V_{m}^{s p}$ in Figure 3.

One way of putting this result is that a healthy balance sheet, that is holding liquidity $m$ when financial constraints are binding, is a public good. A planner who internalizes this effect ensures the socially optimal provision of a public good.

\section{Figure 3. Private and Social Valuation of Net Worth}

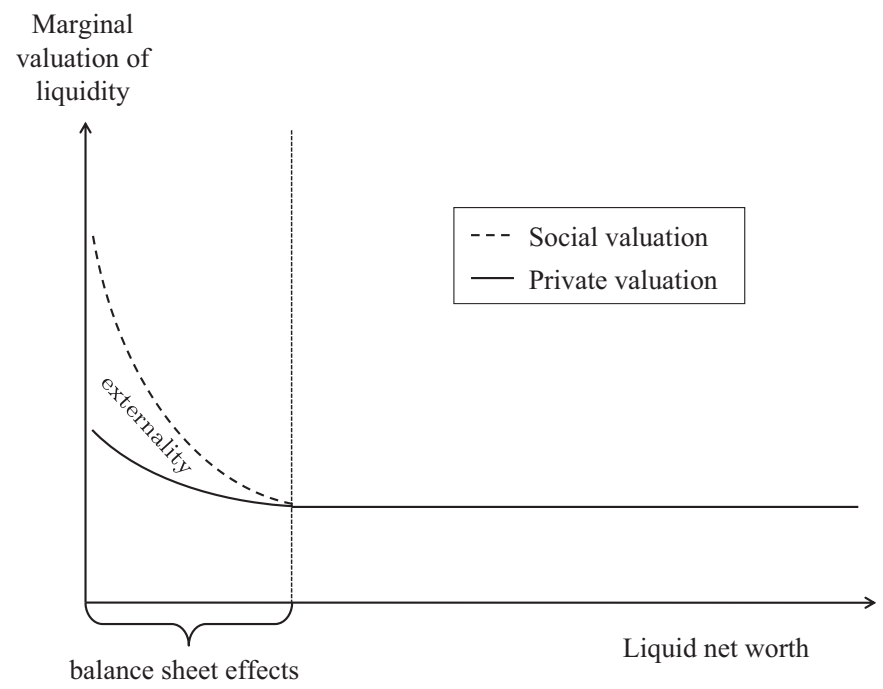

Notes: When liquid net worth falls below a threshold level, contractionary balance sheet effects trigger financial amplification. Private agents do not internalize their pecuniary externalities and undervalue the social benefits of liquid net worth. 


\section{Financing Decisions and Capital Controls}

The marginal valuation of liquidity plays a central role in all intertemporal and most intratemporal allocations of market participants. In the macro and finance literature, the relative marginal valuation of liquidity between two periods is often referred to as pricing kernel, stochastic discount factor or intertemporal marginal rate of substitution. In the analytical example that we describe above, the valuations of liquidity of the planner and of decentralized agents differ, but the two choose the same allocations out of necessity - since there are no free decision margins if the financial constraint is binding.

However, once we introduce additional decision margins, the undervaluation result that we identified in Lemma 1 creates a wide range of distortions in the behavior of decentralized agents. In the following we focus on a subset of the distortions that result from such externalities that affect financing decisions and that have been analyzed in the emerging literature on prudential capital controls (for example, Korinek, 2010a): overborrowing, excessive risk-taking, and excessive short-term debt. In each of these areas, we characterize the distortion analytically in our benchmark model. Then we discuss the related literature, grouped by exchange rate externalities, asset price externalities, and interest rate externalities.

\section{Overborrowing}

An immediate implication of the undervaluation of liquidity (Lemma 1) in emerging economies that experience financial amplification is overborrowing: Since individual agents do not internalize the full social cost of repayments when financial constraints are binding, they take on an excessive debt level and promise excessive repayments compared with the allocations of a constrained planner.

When the economy experiences binding constraints, an excessive debt level implies that decentralized agents experience more amplification, that is sharper declines in the exchange rate and in borrowing capacity than under the allocations chosen by a constrained planner. The free market equilibrium exhibits excessive volatility in the sense that consumption is less smooth than what is optimal. The policy implication of this finding is that it is desirable to impose prudential capital controls on inflows of debt to reduce the external borrowing of private agents.

Analytic illustration: We illustrate our finding on overborrowing by augmenting the problem described above by an additional time period 0 that occurs before the economy exhibits financial amplification in period 1 . Assume that domestic consumers are born with no endowment in period 0 and derive utility

$$
U=\log \left(c_{T, 0}^{\sigma}\right)+\log \left(c_{1}\right)+c_{T, 2} .
$$

The only way to consume in period 0 is to borrow so $d_{0}=c_{T, 0}$ and the liquid tradable resources in period 1 are $m=y_{T}-d_{0}$. Using the value function 
from above, we formulate the consumer's problem as

$$
\max \sigma \log \left(d_{0}\right)+V\left(y_{T, 1}-d_{0} ; y_{T, 1}\right)
$$

and obtain the first-order condition

$$
\frac{\sigma}{d_{0}}=V_{m}(\cdot)
$$

Result 1 (Overborrowing) If $\kappa<\sigma$, a constrained social planner would take on less debt than decentralized agents.

Proof: If $\kappa \geq \sigma$ then the economy is unconstrained in period 1 so $V_{m}^{f b}=1$, $d_{0}=\sigma$ and the allocations of a decentralized agents and a planner coincide. On the other hand, if $\kappa<\sigma$ then the economy is constrained. It follows from Lemma 1 about the valuation of liquidity that for any constrained level of debt, $V_{m}^{c o n}<V_{m}^{s p}$. Therefore we find that in equilibrium $d_{0}^{c o n}>d_{0}^{s p}$. In other words, a constrained social planner would borrow less than private agents in period 0 so as to relax the financial constraint in period 1 .

In comparing the two allocations, it can be seen that the consumption path chosen by the constrained planner is smoother than the path chosen by decentralized agents - the planner introduces a small wedge in the Euler equation between periods 0 and 1 so as to reduce a larger wedge in the Euler equation between periods 1 and 2 . In this sense, the planner reduces intertemporal consumption volatility. In a stochastic version of the model in which the financial constraint only binds in low states of nature, the planner would also reduce consumption volatility across different states of nature (see Jeanne and Korinek, 2010a; Bianchi, 2011).

The constrained planner's equilibrium can be implemented by imposing a Pigouvian tax $\tau$ on debt inflows that closes the wedge between the private valuation $V_{m}^{c o n}$ and the social valuation $V_{m}^{s p}$ of the cost of debt. If a tax on borrowing $d_{0}$ is imposed and the revenue is rebated lump sum, the Euler equation of private consumers becomes $\sigma(1-\tau) / d_{0}=V_{c o n}^{m}(\cdot)$. This condition replicates the planner's constrained optimal intertemporal allocation $\sigma / d_{0}=V_{m}^{s p}(\cdot)$ if the Pigouvian tax is set such that

$$
1-\tau=\frac{V_{m}^{c o n}}{V_{m}^{s p}},
$$

where the derivatives $V_{m}^{s p}$ and $V_{m}^{c o n}$ are evaluated at the planner's allocation. Since $V_{m}^{s p}>V_{m}^{c o n}>1$, the tax is strictly positive but sufficiently small that it does not discourage borrowing to the point where the constraint is loosened. In other words, a planner would impose prudential capital controls so as to reduce the magnitude of crises, but would not attempt to completely avoid them. 
An alternative measure is an unremunerated reserve requirement that imposes an opportunity cost on the lender that equals the size of the Pigouvian tax $\tau$. If the cost of capital for an investor is $r$, then the opportunity cost of an unremunerated reserve requirement $u$ is $u r$, which equals the optimal tax wedge if it is set such that

$$
u=\tau / r=\frac{1-V_{m}^{c o n} / V_{m}^{s p}}{r}
$$

Literature: We categorize the literature on pecuniary externalities and overborrowing according to which relative price is involved. We first discuss exchange rate externalities - as in our analytical illustration - then asset price externalities, and finally interest rate externalities. In the models of financial amplification in the literature, overborrowing is a robust feature.

In the literature on exchange rate externalities, Korinek (2010a) estimates the optimal magnitude of taxes using a sufficient statistics approach. He finds that the externalities of dollar debt in an application to Indonesia ranged from 0 to 30.7 percent over the past two decades and that the optimal level of tax should be on average 1.5 percent. Sufficient statistics approaches show that optimal policy measures can often be expressed as a simple function of a small set of statistics that can be directly obtained from the data (see Chetty, 2009, for a general exposition). Korinek (2010a) shows that the externalities of capital flows during financial amplification can be determined as the product of the social cost of borrowing constraints (as measured by the gap in the Euler equation of constrained agents) and the extent of amplification (as measured by the marginal change in debt in response to the underlying shock). The benefit of sufficient statistics approaches is that they estimate such parameters directly from the data without relying on restrictive assumptions about model structure, behavior and parameters, which makes the resulting policy measures more robust.

Bianchi (2011) quantifies the magnitude of the optimal tax in a dynamic model calibrated to Argentina and finds that it ranges from 0 to 23 percent, with an average of 5.2 percent. The benefit of calibrated equilibrium models is that they allow for greater freedom in the simulation of out-of equilibrium policies. In this sense, the two methodologies are complementary.

Benigno and others $(2010,2011)$ analyze dynamic models of exchange rate externalities and focus on labor market policies to mitigate binding financial constraints. They also describe the effect of such policies on the equilibrium quantity of debt in the economy. However, as we discuss in more detail in the section 'Prudential Capital Controls vs. Ex-Post Intervention', this does not provide insights into optimal prudential policies.

In the literature on asset price externalities, Korinek (2011b) quantifies the level of asset price externalities and the resulting optimal taxation of capital flows to emerging economies in a multicountry DSGE model and finds an optimal tax of 2 percent on average, which is strongly procyclical: for 
each percentage point increase in a country's capital inflows/GDP ratio, it is optimal to raise the tax by 0.87 percentage points. Aizenman (2011) develops a model of fire sale externalities and finds that it is optimal to tax borrowing at a rate of 0.6 percent and use some of the revenue to subsidize reserves in the banking system.

There are a number of additional insights from the quantitative literature on asset price externalities that are calibrated to advanced economies. Jeanne and Korinek (2010b) and Bianchi and Mendoza (2011) show that optimal prudential regulation is highly cyclical. Prudential taxes are only warranted if there is a risk of binding constraints in the period of repayment. ${ }^{14}$ Specifically, the magnitude of externalities and capital controls is determined by the probability and expected size of financial amplification effects when the capital inflow is to be repaid. Jeanne and Korinek (2010b) find that externalities are likely to be largest during booms when risk builds up, and prudential controls should be raised during such times. They are likely to be lowest at the bottom of crises when there is no scope for further deterioration in the economy, and prudential controls can be reduced at that timepotentially to zero. The optimal level of prudential capital controls should therefore adjust procyclically.

Nikolov (2011) describes a model of asset price externalities that is calibrated such that the most productive agents are always financially constrained. In that situation, their borrowing is a corner solution that is determined by the constraint, and optimal prudential taxes have no effect. Jeanne and Korinek (2010b) also obtain this result if they calibrate borrowers to be sufficiently impatient. The lesson is that studying optimal prudential policies requires a framework in which the borrowing choices of individuals are not determined by binding constraints, such as models of occasionally binding constraints. By contrast, DSGE models that assume that financial constraints are always binding so that they can be solved by perturbation methods cannot provide insights into prudential regulation based on pecuniary externalities.

In the literature on interest rate externalities, Caballero and Krishnamurthy (2004) find overborrowing in a model in which domestic and international collateral constraints interact to amplify shocks because the interest rate at which distressed agents borrow rises further the more constrained they are. A planner in their model would instruct agents to borrow less ex-ante so that there is more liquidity available in the domestic credit market during crises. This lowers the cost of borrowing and redistributes from unconstrained lenders to constrained borrowers who value liquidity comparatively more highly.

\footnotetext{
${ }^{14}$ However, even if prudential taxes are not employed in some time periods, the equilibrium in a multiperiod general equilibrium model will still be affected by the expectation of future intervention.
} 
The literature on overborrowing and capital controls implicitly assumes that any capital inflow to emerging economies is in the form of one-period foreign currency debt. Let us generalize our findings to the full range of the liability structure of an emerging economy in the following.

\section{Excessive Risk-Taking and Underinsurance}

The externalities of financial amplification induce private market participants to take on too much aggregate risk in their financing decisions, even if they have access to state-contingent insurance instruments. Emerging economies face a risk-return trade-off in their financing decisions: instruments such as dollar debt are cheap - they are available at comparatively low interest rates-but they impose significant risk on borrowers in case the exchange rate depreciates. On the other hand, financial instruments that involve more risk-sharing, such as local currency debt or, even more so, equity and FDI, require a higher return that compensates international investors for the additional risk.

Private agents choose their liability structure according to a private risk/return trade-off, but fail to internalize that a risky private balance sheet also imposes social costs. Put differently, they do not have proper incentives to take precautions against financial amplification effects and buy too little crisis insurance compared with a constrained planner.

This creates a natural role for prudential capital controls that discourage emerging market agents from issuing excessively risky financial liabilities. Such controls aim to raise the private cost of different financial instruments to their social cost and force private agents to account for the expected social loss that they create by exposing the country to greater crisis risk.

Analytic illustration: In our analytic model, we introduce two states of the world in period 1 and allow consumers to interact with risk-averse international investors and make a state-contingent financing/insurance decision in period 0 . Assume that consumers value consumption according to the utility function $U=c_{T, 0}+u\left(c_{1}\right)+c_{T, 2}$ and that period 1 output can take on two realizations $y_{T, 1} \in\left\{y^{L}, y^{H}\right\}$ with probabilities $p$ and $1-p$. Consumers sell state-contingent securities $d_{0}^{L}$ and $d_{0}^{H}$ to large international investors who buy them at prices $p(1+\rho)$ and $(1-p)$ each. In other words, investors are paying the expected value for payoffs in the high state of nature, but they are averse to the low state of nature and are willing to pay a premium $(1+\rho)$ for payoffs in that state. ${ }^{15}$

The maximization problem of domestic consumers is

$$
\max \left[p(1+\rho) d_{0}^{L}+(1-p) d_{0}^{H}\right]+E_{i}\left\{V\left(y^{i}-d_{0}^{i} ; y^{i}\right)\right\}
$$

where the expectation is taken over $i \in\{L, H\}$. The resulting first-order

\footnotetext{
${ }^{15}$ Risk-averse international investors are an important aspect of our model; otherwise domestic consumers could costlessly insure against domestic shocks.
} 
condition on $d_{0}^{L}$ is

$$
1+\rho=V_{m}\left(m^{L}\right) .
$$

Result 2 (Excessive Risk-Taking) A constrained social planner would commit to smaller repayments $\mathrm{d}_{0}^{\mathrm{L}}$ in the low state of nature than decentralized agents.

Proof: According to equation (15), consumers choose a state contingent repayment that leaves them constrained in the low state of nature $L$, since the cost of insurance against this state is greater than the marginal value of liquid resources in unconstrained states $V_{m}^{f b}=1$. This first-order condition pins down a unique level of $d_{0}^{L}$ since the value function $V$ is strictly concave in that region. By contrast, the first-order condition on repayments in the high state $d_{0}^{H}$ is $V_{m}^{f b}\left(m^{H}\right)=1$, which implies that the economy will be unconstrained in the high state. Per Lemma 1 , the planner values liquidity more highly than decentralized agents in the constrained state $L$, but the two value liquidity equally in the unconstrained state $H$. By substituting the derivative of the planner's value function in the first-order condition (15), it can be seen that the planner would promise lower repayments in the low state of nature, that is the planner's financing choices leave the economy less exposed to binding constraints and financial amplification.

The portfolio decision of consumers can be interpreted as a risk/return tradeoff: they sell claims on the low state of nature to the point where they incur binding constraints ("risk") because foreign investors are willing to buy such claims at a higher price ("return"). The planner perceives the cost of binding constraints higher and will therefore sell fewer claims $d_{0}^{L}$. If the low state of nature materializes, the planner is responsible for smaller repayments, there is less amplification, and consumption $c_{T, 1}$ declines less severely than in the decentralized equilibrium. In this sense a planner takes on less risk in her financing decisions or buys more insurance against adverse states of nature than decentralized agents.

The planner's equilibrium can be implemented via Pigouvian taxation or unremunerated reserve requirements on payoffs in the low state of nature $d_{0}^{L}$ according to the formulas (13) and (14). Consumers and the planner value payoffs in the unconstrained high state $d_{0}^{H}$ equally.

We can view real-world securities as different combinations of statecontingent payoffs $\left(d_{0}^{L}, d_{0}^{H}\right)$. For example, foreign-currency-denominated debt would correspond to a pair $d_{0}^{L}>d_{0}^{H}$ - consumers who borrow in foreign currency have to repay more in low states of nature when a country's exchange rate depreciates. CPI-indexed local currency debt (real debt) would correspond to $d_{0}^{L}=d_{0}^{H}$. On the other hand, nonindexed local currency debt would correspond to $d_{0}^{L}<d_{0}^{H}$ since it entail lower repayments in low states than in high states of nature. FDI may be viewed as a contract in which $d_{0}^{L} \approx 0$ since profits are only repatriated in good times. The different weights 
Table 1. Externalities Imposed by Different Financial Instruments in Indonesia, 1997/98

\begin{tabular}{lccc}
\hline Asset Category & $\begin{array}{c}\text { Real Gross } \\
\text { Return (\%) }\end{array}$ & $\begin{array}{c}\text { Externality in } \\
1998(\%)\end{array}$ & $\begin{array}{c}\text { Optimal } \\
\text { Tax (\%) }\end{array}$ \\
\hline Dollar debt & 218 & 30.7 & 1.54 \\
GDP-indexed dollar debt & 190 & 26.8 & 1.34 \\
CPI-indexed rupiah debt & 100 & 14.1 & 0.71 \\
Rupiah debt & 63 & 8.9 & 0.44 \\
Stock market index & 44 & 6.2 & 0.31 \\
\hline
\end{tabular}

on payoffs in the high state and on externality-rife payoffs in the low state is what is responsible for the pecking order of externalities in Table 1.

Literature: In the literature on exchange rate externalities, Korinek (2010a) employs a sufficient statistics approach to estimate the externalities imposed by different forms of financial instruments during the 1997/98 crisis in Indonesia. He finds that a marginal outflow of one dollar during the crisis imposed an externality of 14 cent on other borrowers. The first column of Table 1 reports the gross return of different financial instruments. The second column multiplies this by 14 percent to obtain the marginal externality of each type of instrument under the assumption of a one-year maturity. The third column determines the optimal tax rate if crises occur on average every 20 years.

In the table, different forms of capital flows are ranked according to a pecking order of decreasing externalities: dollar debt is one of the most dangerous forms of finance, since the local currency typically depreciates during crises, which inflates the value of dollar liabilities just when domestic agents are least able to service their debt. The real gross return on dollar debt is reported as 218 percent. CPI-indexed debt contracts or rupiah debt impose considerably smaller externalities as they avoid such adverse valuation effects. Investments in the stock market allow for a considerable degree of risk-sharing with foreigners, which reduces the externalities even more. However, they are still associated with externalities, since international investors often sell stocks during financial crises, which leads to capital outflows and pressure on the exchange rate. These theoretical predictions about the riskiness of different forms of finance closely mirror the empirical findings on the effects of different forms of financial liabilities on stability and growth (see, for example, Mauro and others, 2007).

Korinek $(2007,2009)$ develops a structural model to analyze the trade-off of emerging countries that can borrow in local or foreign currency. Local currency is a better insurance instrument since the exchange rate depreciates during crises, but it typically commands a risk premium. He finds that the externalities created by dollar debt warrant a differential tax between dollar and local currency debt of 0.66 percent. In equilibrium, such a tax would decrease the incidence of crises, which reduces the variability of the exchange rate and lowers the risk premium on local currency debt. 
Caballero and Krishnamurthy (2003) finds that individual market participants do not internalize that less dollar borrowing and more contingent forms of debt would mitigate the pecuniary externalities on interest rates and the exchange rate that emerging market agents experience during times of binding financial constraints.

\section{Excessive Short-Term Debt}

Another manifestation of excessive risk-taking is that decentralized agents take on too much short-term debt (see Korinek, 2010a; Bengui, 2011b). Long-term debt insures emerging economies against rollover risk during systemic crises, that is against the risk that interest rates rise or credit is rationed precisely when the country most needs funding. During such rollover crises, financial amplification effects occur and give rise to externalities. Individual market participants do not internalize this and take on too little long-term debt as insurance against rollover risk.

Analytic illustration: We introduce a long-term bond in the analytic model of the section 'Overborrowing'. The utility function of domestic consumers is given by equation (12), and they finance their period 0 consumption by issuing short-term debt $d_{0}$ at gross interest rate 1 and long-term debt $d_{0}^{L T}$ to be repaid in period 2 at an interest rate $1+\xi$, where $\xi>0$ reflects an exogenous term premium,

$$
c_{T, 0}=d_{0}+d_{0}^{L T} .
$$

For simplicity, we assume that the consumer's long-term debt does not affect the renegotiation problem at time 1 since it does not need to be rolled over. ${ }^{16}$ It follows that the consumer's optimization problem is

$$
\max \sigma \log \left(d_{0}+d_{0}^{L T}\right)+V\left(y_{T, 1}-d_{0} ; y_{T, 1}\right)-(1+\xi) d_{0}^{L T} .
$$

The first-order conditions on $d_{0}$ and $d_{0}^{L T}$ imply

$$
\frac{\sigma}{c_{T, 0}}=V_{m}(\cdot)=1+\xi \text {. }
$$

Result 3 (Excessive Short-term Debt) A constrained planner would take on less short-term debt $\mathrm{d}_{0}$ and more long-term debt $\mathrm{d}_{0}^{\mathrm{LT}}$ than decentralized agents.

Proof: The second equality pins down a unique level of short-term debt $d_{0}$ since the value function $V$ is strictly concave in the constrained region where $V_{m}>1$. Lemma 1 implies that the social planner would contract a smaller

\footnotetext{
${ }^{16}$ More generally, we could assume that a fraction of the long-term debt has to be rolled over in period 1 and that this fraction enters the borrowing constraint. Our basic results would be unaffected.
} 
level of $d_{0}$ than decentralized agents. The first equality then pins down period 0 consumption and, via the period 0 budget constraint, the level of long-term debt. Since period 0 consumption $c_{T, 0}$ is identical in the allocations of the decentralized equilibrium and the planner, a smaller level of short-term debt implies that the planner takes on a higher level of long-term debt than decentralized agents.

The planner's equilibrium can again be implemented by imposing a Pigouvian tax $\tau$ or an unremunerated reserve requirement $u$ on short-term debt, as given by equations (13) and (14).

Literature: Bengui (2011b) analyzes the incentives for borrowers to take on short-term debt in a model of financial amplification based on asset price externalities akin to Kiyotaki and Moore (1997). In his model, long-term debt provides borrowers with insurance since its value moves in parallel with asset prices, but it is more expensive than short-term debt. Individual agents do not internalize the full social benefits of insurance and therefore take on excessive short-term debt.

\section{Implementation}

Instruments: In much of the existing literature on prudential capital controls, optimal policy measures are derived as tax wedges that could be implemented in a variety of equivalent ways. Direct Pigouvian taxation of capital inflows has the benefit of being transparent and raising revenue while offsetting a distortion (this is a benefit of all forms of Pigouvian taxation). In practice, a common device to implement prudential capital controls are unremunerated reserve requirements (URRs), which require international investors to hold part of any inflow in a reserve account that does not earn interest. The opportunity cost of not receiving interest can be viewed as a Pigouvian tax. ${ }^{17}$ In the literature that we surveyed above, the constrained optima could equivalently be implemented by price or quantity regulations. This is because the existing literature makes strong homogeneity assumptionsfor example, there is a "representative" borrower, implying that all borrowers take on identical forms and amounts of finance. Furthermore, a given exchange rate movement creates identical balance sheet effects for all agents in the economy.

The duality between price regulations and quantity regulations no longer holds when there is heterogeneity between economic agents that policymakers cannot take into account or when there is uncertainty about the economic environment, as was emphasized by Weitzman (1974). Perotti and Suarez (2011) study the desirability of price vs. quantity controls in the context of banking regulation in which a regulator faces heterogeneous banks but has to impose uniform regulations. If banks differ mostly in credit

\footnotetext{
${ }^{17}$ However, Korinek (2010b) cautions that the opportunity cost of holding reserves in the current economic environment with low global interest rates are close to zero and fluctuate strongly with small changes in global interest rates, making the policy instrument less reliable.
} 
opportunities, they find that price controls are desirable, as they allow individual banks to optimally adjust the size of their portfolios while offsetting pecuniary externalities in the aggregate supply of credit. If banks differ mostly in gambling incentives, quantity controls are desirable since they prevent the most "reckless" banks from taking on excessive quantities of credit. In practice both dimensions of heterogeneity seem relevant, implying that a combination of taxes and quantity controls may be constrained optimal.

Applying this intuition to prudential capital controls would suggest that if the recipients of capital inflows differ mostly in profitability, then price-based controls are desirable since they allow the market to allocate the most capital to the most profitable agents. If recipients differ mostly in riskiness, then quantity controls such as limits on leverage may be optimal since they prevent excessive risk-taking. In practice, a combination of the two may be desirable. However, further research on this topic is needed.

Desirability and effectiveness: Forbes (2005) argues that prudential capital controls may be undesirable because they increase the cost of finance for private firms and give rise to evasion. However, raising the private cost of capital inflows to their social cost is precisely the goal of such regulation, just as environmental regulation is designed to raise the cost of pollution in order to discourage it. Furthermore, an increase in the cost of capital for agents who are prone to financial constraints would in fact be evidence that capital controls are effective.

\section{Extensions}

This section covers several extensions of the basic framework of prudential capital controls that was described in the previous section. It begins by focusing on the role of ex-ante prudential controls vs. ex-post policy interventions to respond to financial crises. We proceed by discussing distortions in real investment and growth. Next we cover the implications of global interest rates for the level of prudential capital controls. Finally we describe the externalities that prudential capital controls in one country may impose on other countries and whether there is a role for global coordination.

\section{Prudential Capital Controls vs. Ex-Post Intervention}

The previous section covered prudential capital controls that are designed to mitigate the pecuniary externalities that arise during financial amplification ex-ante, that is before a financial crisis occurs. A number of recent papers have analyzed the scope for ex-post intervention, that is for policies that can be employed once an emerging economy experiences a financial crisis. The general lesson of this literature is that it is optimal to use a mix of both ex-ante and ex-post policy measures to address financial crises.

Benigno and others $(2010,2011)$ study an emerging economy and introduce a policymaker who has an instrument to shift labor into the 
tradable sector as a second-best device to appreciate the country's exchange rate and relax its borrowing constraint. Benigno and others find that it is desirable to use such policies when the financial constraint is binding to mitigate the severity of financial crises.

If financial crises can be mitigated in this fashion, it is optimal for emerging economies to reduce precautionary saving, that is to increase the amount of their borrowing. Some have interpreted this to imply that prudential controls on borrowing are undesirable. However, this confuses positive and normative analysis. Comparing equilibrium quantities between the free market equilibrium and the allocation of a planner who has multiple instruments cannot be used as a guide for normative policy analysis since every instrument affects every equilibrium quantity in general equilibrium, as emphasized, for example, by Atkinson and Stiglitz (1980). In the context of Benigno and others $(2010,2011)$ the planner determines both the use of labor market policies to relax binding constraints ex-post (which has the general equilibrium effect of increasing borrowing) and the amount borrowed in the economy (which is, ceteris paribus, less than what decentralized agents would borrow).

To conduct a proper normative analysis of whether prudential capital controls are warranted in addition to ex-post policy instruments requires a comparison of the quantity borrowed by decentralized agents and a planner under ceteris paribus conditions, that is while holding other policy measures such as the labor market policies in Benigno and others constant. A second (and equivalent) approach is to focus on optimal tax wedges as in Atkinson and Stiglitz (1980) rather than equilibrium quantities.

Jeanne and Korinek (2011b) study the relative desirability of prudential controls vs. ex-post interventions in models of financial amplification and focus on optimal tax wedges. They find that it is desirable to use a combination of prudential and ex-post instruments in a wide range of settings, including one that is similar to Benigno and others. Additional ex-post policy measures covered in Jeanne and Korinek (2011b) include measures to support declining asset prices. At the optimum, the expected marginal cost/benefit ratios of all policy measures in their paper are equalized.

Céspedes, Chang, and Velasco (2011) analyze an economy with banks that hold foreign currency debt and study how different forms of bailout policies can be used to mitigate financial amplification. They find that the most effective use of government funds is to lend directly to banks, since recapitalized banks can leverage up and lend a multiple of their capital to firms. This policy dominates direct lending to firms or indirect bank bailouts through exchange rate intervention.

Jeanne and Korinek (2011c) investigate the use of prudential taxes that are accumulated in a reserve fund and used to support asset prices or exchange rates when the economy experiences financial amplification effects. This policy design hits two birds with one stone, since both the prudential tax and the price support contribute to reducing the incidence and severity of financial crises. 


\section{Prudential Capital Controls, Investment, and Growth}

Economists and policymakers alike often wonder whether imposing capital controls may discourage investment and hurt long-term growth in emerging economies. The lesson from the new economics of prudential capital controls is that capital controls make allocations more efficient. In the presence of externalities, the free market equilibrium is generically inefficient. Imposing proper regulation achieves a Pareto improvement. Returning to our earlier analogy, if we impose regulations on environmental pollution, those industrial activities that create pollution will be reduced, but this improves welfare since the regulation counteracts an externality.

When private agents in an emerging economy decide how much risk to take on in their investment decisions, they systematically underestimate the social cost of losses in bad times, as we emphasized in Lemma 1. The real investment decisions of individual agents are therefore distorted toward excessive investment in projects that are procyclical and create socially costly liquidity shortfalls in constrained states, and toward insufficient investment in countercyclical projects that deliver socially valuable payoffs in such states, making the real payoffs of the economy excessively cyclical (Korinek, 2010a).

This contrasts markedly with the view that is prevalent in some circles that policymakers who decide on the optimal degree of financial regulation face a Pareto frontier along which there is a trade-off between financial stability and allocative efficiency, similar to the tradeoff of risk vs. return faced by portfolio investors. The prudential view of capital controls clearly rejects that view: in economies that are prone to financial amplification effects, financial regulation simultaneously enhances stability and efficiencyin the absence of regulation, an economy is inside the Pareto frontier, and well-designed regulation can make everybody better off.

Caballero and Lorenzoni (2009) study the effects of booms and busts in exchange rates on capital investment in the tradable sector and identify a pecuniary externality that affects the exchange rate and wages. The authors observe that exchange rate appreciations during booms reduce investment in the tradable sector. As in the framework discussed in the previous section, individual agents do not internalize that the smaller size of the tradable sector will imply a greater scarcity of tradable liquidity and hence a stronger depreciation of the real exchange rate once the forces behind the appreciation subside. The depreciation in the real exchange rate constitutes a pecuniary externality that reduces consumer welfare, since consumers earn their wages in nontradable domestic goods.

The authors find that this externality may provide a rationale for intervention during booms and busts in the exchange rate: during booms, restricting the rise in the exchange rate, for example by subsidizing tradable capital holdings, may prevent the tradable sector from shrinking excessively, which would mitigate the decline in the exchange rate and in real wages later on. Similarly, an intervention once the boom in the exchange rate has reversed may help the tradable sector to recover more quickly. 
Jeanne and Korinek (2011a) analyze an economy in which private agents engage in collateralized borrowing and have access to an investment technology that enhances the productivity of their fixed assets and generates economic growth every period. When the economy is hit by an adverse shock and experiences financial amplification, the resulting credit crunch forces domestic agents to temporarily cut back on investment. This reduces growth for the duration of the crisis episode and leads to a permanently lower path of output. Jeanne and Korinek (2011a) show that proper prudential controls on capital inflows slow down the buildup of debt during boom times, which mitigates the busts in the economy. Although the growth rate is marginally reduced in boom times, the economy avoids the severe crises that characterize the free market equilibrium and in which growth declines substantially. The net effect is that long-run growth is higher under the optimally chosen path of prudential capital controls than in the free market equilibrium-consistent with the view that internalizing externalities increases welfare.

\section{Interest Rates and Financial Fragility}

A global environment of low interest rates is particularly conducive to create financial fragility and the associated externalities. As we emphasized before, private market participants choose their liability structure as an optimal trade-off between risk and return. Lower interest rates increase the incentive to borrow and induce market participants to take on higher debt. When the economy experiences a negative shock in an ensuing period-no matter whether this shock originates within or outside the country - a higher debt burden implies that borrowers are more exposed to such shocks and experience greater financial instability in the form of stronger financial amplification effects and crises.

There have been a number of reasons why emerging market economies experienced low interest rates in recent times, including neo-mercantilism and crises in other parts of the world economy. Steiner (2011) emphasizes that the precautionary motives of some central banks led to large foreign reserve accumulation, which led to an increase in the global supply of savings, pushed down the world interest rate and in turn made deficit countries more vulnerable to financial fragility and externalities. Korinek (2011b) develops a model in which financial crises in one part of the world economy lead to outflows of hot money to other countries. In the ensuing years, international investors have to find another place to invest their savings, and the supply of capital to healthy economies is increased, leading to lower interest rates in that part of the world economy. This makes the recipient countries more vulnerable to future financial crises. Korinek and Serven (2010) argue that neo-mercantilism, that is accumulating reserves to foster exports, is likely to have played a significant role in pushing down world interest rates in the most recent decade. 


\section{Prudential Capital Controls and Currency Wars}

The renewed interest in prudential capital controls in recent years has led to concerns that imposing such controls in one country may lead to negative spillover effects on other countries. This brings up the question of whether global coordination of such policies is desirable. Since the capital account is about the intertemporal allocation of resources among economies, the main international variable through which capital account policies affect other countries is the world interest rate. For example, if a large country in the world economy imposes prudential capital controls, this reduces the global demand for capital and ceteris paribus leads to a decline in world interest rates. As we emphasized in the previous subsection, this will, at the margin, lead other countries to borrow more and be exposed to greater risk of financial crises.

If each country optimally regulates the externalities it experiences from capital inflows, Korinek (2011a) shows that the resulting equilibrium is constrained Pareto efficient and there is no need for global coordination of regulatory policies. However, this result breaks down if countries do not (or cannot) optimally regulate their capital inflows, for example because of targeting problems.

If countries impose capital controls so as to manipulate the world interest rate (their intertemporal terms of trade), then the resulting equilibrium is Pareto inefficient, as in any model of monopoly power. For example, if a large borrowing country imposes capital controls in order to reduce world demand for capital, push down the world interest rate and obtain cheaper finance, then lowering the interest rate redistributes income from lenders to borrowers (with zero-sum welfare effects) and in addition reduces the quantity transacted (with negative welfare effects).

Bengui (2011a) analyzes a multicountry framework of banking and liquidity regulation in the spirit of Caballero and Krishnamurthy (2004) in which liquidity is a global public good. He shows that national regulators may have incentives to require domestic banks to hold less than the socially efficient level of liquidity because domestic banks can free-ride on the liquidity provision of banks in other countries. Global coordination among regulators avoids this free-riding problem and induces them to increase liquidity requirements on banks. This also captures the phenomenon that national regulators are reluctant to raise liquidity requirements in the absence of global coordination.

\section{Conclusion}

This paper provided an overview of the emerging literature on prudential capital controls. The view of this literature is that capital controls may be desirable to counteract the pecuniary externalities that arise from modern financial crises that involve balance sheet effects and financial amplification. It is rational for private market participants to not internalize such balance sheet effects and make financing and investment decisions that impose 
externalities on the rest of the economy by increasing the aggregate level of financial fragility. In particular, in the absence of regulation, private market participants take on an excessive level of debt, issue excessively risky financial instruments and engage in excessive short-term borrowing.

According to this literature, policymakers should aim to internalize such externalities and coordinate the actions of market participants toward a lower level of financial fragility. They could do so by imposing capital controls that discourage excessively risky financial instruments, in particular short-term dollar-denominated debt. Mitigating these externalities would increase both stability and efficiency in the affected emerging market economies and would make everybody better off.

By providing clear theoretical justifications for controls on capital inflows that are based on prudential concerns, this literature also delineates its limitations. In particular, the new economics of prudential capital controls cannot justify capital controls that go beyond prudential considerations. For example, it is difficult to justify fully closed capital accounts on prudential grounds.

Our survey also points toward a number of directions in which further research is warranted. Prudential capital controls are by design second-best policies. At a microeconomic level, we need to better understand the breadth of balance sheet effects that occur during episodes of financial amplification and how they relate to macroeconomic phenomena. This may point us toward how to mitigate the distortions that give rise to such episodes more directly. At a macroeconomic level, a better understanding of policies to deal with financial crises once they occur is highly desirable and would reduce the burden placed on prudential policies. The most recent global financial crisis has starkly highlighted our unpreparedness in this area. Finally, at the level of implementation, more research is needed on what forms of capital controls are most desirable and effective in preventing the buildup of risks that may result in large financial crises.

\section{REFERENCES}

Aghion, P., P. Bacchetta, and A. Banerjee, 2000, "A Simple Model of Monetary Policy and Currency Crises," European Economic Review, Vol. 44, No. 4-6, pp. $728-38$.

, 2001, "Currency Crises and Monetary Policy in an Economy with Credit Constraints," European Economic Review, Vol. 45, No. 7, pp. 1121-50.

Aizenman, J., 2011, "Hoarding International Reserves Versus a Pigovian TaxCum-Subsidy Scheme," Journal of Economic Dynamics and Control, Vol. 35, No. 9, pp. 1502-13.

Arnott, R.J., B.C. Greenwald, and J.E. Stiglitz, 1992, "Information and Economic Efficiency," Information Economics and Policy, Vol. 6, No. 1, pp. 77-88.

Atkinson, A.B., and J.E. Stiglitz, 1980, Lectures on Public Economics (New York: McGraw-Hill).

Bengui, J., 2011a, "Macro-Prudential Policy Coordination and Global Regulatory Spillovers," University of Maryland, manuscript. 
, 2011b, "Systemic Risk and Inefficient Debt Maturity," (mimeo, University of Maryland).

Benigno, G., others 2010, "Financial Crises and Macro-Prudential Policies," (mimeo, University of Virginia).

Benigno, G, others 2011, "Revisiting Overborrowing and its Policy Implications," in Monetary Policy Under Financial Turbulence, ed. by L.F. Céspedes, R. Chang, and D. Saravia (Santiago, Chile: Central Bank of Chile), pp. 145-85.

Benmelech, E., and N.K. Bergman, 2011, "Bankruptcy and the Collateral Channel," Journal of Finance, Vol. 66, No. 2, pp. 337-78.

Bernanke, B., and M. Gertler, 1989, "Agency Costs, Net Worth, and Business Fluctuations," American Economic Review, Vol. 79, No. 1, pp. 14-31.

Bhattacharya, S., and D. Gale, 1987, "Preference Shocks, Liquidity and Central Bank Policy," in New Approaches to Monetary Economics, ed. by W.A. Barnett and K.J. Singleton (New York: Cambridge University Press), pp. 69-88.

Bianchi, J., 2011, "Overborrowing and Systemic Externalities in the Business Cycle," American Economic Review, forthcoming.

Bianchi, J., and E.G. Mendoza, 2011, "Overborrowing, Financial Crises and Macroprudential Policy," University of Maryland, manuscript.

Borio, C., 2011, "Rediscovering the Macroeconomic Roots of Financial Stability Policy: Challenges and a Way Forward," Annual Review of Financial Economics, Vol. 3, forthcoming.

Burnside, C., M. Eichenbaum, and S. Rebelo, 2001, "Prospective Deficits and the Asian Currency Crisis," Journal of Political Economy, Vol. 109, No. 6, pp. 1155-97.

, 2008, "Currency Crisis Models," in The New Palgrave: A Dictionary of Economics, ed. by S.N. Durlauf and L.E. Blume (Basingstoke: Palgrave Macmillan, 2nd ed.).

Caballero, R.J., and A. Krishnamurthy, 2001, "International and Domestic Collateral Constraints in a Model of EmergingMarket Crises," Journal of Monetary Economics, Vol. 48, No. 3, pp. 513-48.

_ , 2003, "Excessive Dollar Debt: Financial Development and Underinsurance," Journal of Finance, Vol. 58, No. 2, pp. 867-94.

_ 2004, "Smoothing Sudden Stops," Journal of Economic Theory, Vol. 119, No. 1, pp. 104-27.

Caballero, R.J., and G. Lorenzoni, 2009, "Peristent Appreciations and Overshooting: A Normative Analysis," (mimeo, MIT).

Carlstrom, C., and T.S. Fuerst, 1997, "Agency Costs, Net Worth, and Business Fluctuations: A Computable General Equilibrium Analysis," American Economic Review, Vol. 87, No. 5, pp. 893-910.

Céspedes, L.F., R. Chang, and A. Velasco, 2011, "Exchange Market Intervention as Unconventional Monetary Policy," manuscript.

Chetty, R., 2009, "Sufficient Statistics for Welfare Analysis: A Bridge Between Structural and Reduced-Form Methods," Annual Review of Economics, Vol. 1, pp. 451-87.

Cordoba, J.-C., and M. Ripoll, 2004, "Credit Cycles Redux," International Economic Review, Vol. 45, No. 4, pp. 1011-46.

Fahri, E, and J. Tirole, 2011, "Collective Moral Hazard, Maturity Mismatch, and Systemic Bailouts," American Economic Review, forthcoming. 
Fisher, I., 1933, "The Debt-Deflation Theory of Great Depressions," Econometrica, Vol. 1, No. 4, pp. 337-57.

Flood, R.P., and P.M. Garber, 1984, "Collapsing Exchange Rate Regimes: Some Linear Examples," Journal of International Economics, Vol. 17, pp. 1-13.

Forbes, K.J., 2005, "The Microeconomic Evidence on Capital Controls: No Free Lunch,” NBER Working Paper 11372.

Frankel, J.A., 2005, "Contractionary Currency Crashes in Developing Countries," IMF Staff Papers, Vol. 52, No. 2, pp. 149-92.

Friedman, M., 1953, "The Case for Flexible Exchange Rates," in Essays in Positive Economics, ed. by M. Friedman (Chicago: University of Chicago Press), pp. 157-203.

Geanakoplos, J.D., and H.M. Polemarchakis, 1986, "Existence, Regularity, and Constrained Suboptimality of Competitive Allocations When the Asset Market is Incomplete," Cowles Foundation Paper, 652.

Gertler, M., S. Gilchrist, and F.M. Natalucci, 2007, "External Constraints on Monetary Policy and the Financial Accelerator," Journal of Money Credit and Banking, Vol. 39, No. 2-3, pp. 295-330.

Greenwald, B.C., and J.E. Stiglitz, 1986, "Externalities in Economies with Imperfect Information and Incomplete Markets," Quarterly Journal of Economics, Vol. 90 (May), pp. 229-64.

Hart, O., 1975, "On the Optimality of Equilibrium When the Market Structure is Incomplete," Journal of Economic Theory, Vol. 11, pp. 418-43.

Jacklin, C.J., 1987, "Demand Deposits, Trading Restrictions and Risk Sharing," in Contractual Arrangements for Intertemporal Trade, ed. by E.C. Prescott and N. Wallace (Minneapolis: University of Minnesota Press).

Jeanne, O., and A. Korinek, 2010a, "Excessive Volatility in Capital Flows: A Pigouvian Taxation Approach," American Economic Review, Vol. 100, No. 2, pp. 403-7. , 2010b, "Managing Credit Booms and Busts: A Pigouvian Taxation Approach," NBER Working Paper, w16377.

_ 2011a, "Booms, Busts and Growth," (mimeo, University of Maryland). , 2011b, "Macroprudential Regulation Versus Mopping up After the Crash," (mimeo, University of Maryland).

_ 2011c, "Pecuniary Externalities and Second-Best Interventions," (mimeo, University of Maryland).

Jeanne, O., A. Subramanian, and J. Williamson, 2012, Who Needs to Open the Capital Account? (Washington, DC: Peterson Institute for International Economics).

Keynes, J.M., 1929, "The German Transfer Problem," Economic Journal, Vol. 39, No. 153 , pp. $1-7$.

Kiyotaki, N., and J. Moore, 1997, "Credit Cycles," Journal of Political Economy, Vol. 105, No. 2, pp. 211-48.

Kocherlakota, N., 2000, "Creating Business Cycles Through Credit Constraints," Federal Reserve Bank of Minneapolis Quarterly Review, Vol. 24, pp. 2-10.

Korinek, A., 2007, "Dollar Borrowing in Emerging Markets," (Dissertation; New York: Columbia University).

, 2009, "Excessive Dollar Borrowing in Emerging Markets: Balance Sheet Effects and Macroeconomic Externalities," (mimeo, University of Maryland). 
, 2010a, "Regulating Capital Flows to Emerging Markets: An Externality View," (mimeo, University of Maryland).

, 2010b, "Regulating Capital Flows to Emerging Markets: Design and Implementation Issues," University of Maryland, manuscript.

_ , 2011a, "Capital Controls and Currency Wars," (mimeo, University of Maryland). , 2011b, "Hot Money and Serial Financial Crises," IMF Economic Review, Vol. 59, No. 2, pp. 306-39.

Korinek, A., and L. Serven, 2010, "Undervaluation Through Foreign Reserve Accumulation: Static Losses, Dynamic Gains," World Bank Policy Research Working Paper 5250.

Krugman, P.R., 1979, "A Model of Balance-of-Payments Crises," Journal of Money, Credit and Banking, Vol. 11, No. 3, pp. 311-25.

, 1999, "Balance Sheets, the Transfer Problem, and Financial Crises," in International Finance and Financial Crises: Essays in Honor of Robert P. Flood Jr, ed. by P. Isard, A. Razin, and A.K. Rose (Washington, DC: International Monetary Fund), pp. 31-44.

_ 2001, "Analytical Afterthoughts on the Asian Crisis" in Economy Theory, Dynamics and Markets. Essay in Honour of Ryuzo Sato, ed. by T. Negishi, R.V. Ramachandran and K. Mino (Boston: Kluwer Academic Publishers).

Laffont, J.-J., 1987, "Externalities," in The New Palgrave: A Dictionary of Economics, ed. by J. Eatwell, M. Milgate, and P. Newman (Basingstoke: Palgrave Macmillan).

Lorenzoni, G., 2008, "Inefficient Credit Booms," Review of Economic Studies, Vol. 75, No. 3, pp. 809-33.

Magud, N., C.M. Reinhart, and K. Rogoff, 2011, "Capital Controls: Myth and Reality-A Portfolio Balance Approach,” NBER Working Paper, w16805.

Mauro, P., others 2007, "Reaping the Benefits of Financial Globalization," IMF Discussion Paper.

McKinnon, R.I., and H. Pill, 1998, "International Overborrowing: A Decomposition of Credit and Currency Risks," World Development, Vol. 26, No. 7, pp. 1267-82.

Mendoza, E.G., 2002, "Credit, Prices, and Crashes: Business Cycles with a Sudden Stop," in Preventing Currency Crises in Emerging Markets, ed. by S. Edwards and J.A. Frankel (Chicago: University of Chicago Press).

_ 2010, "Sudden Stops, Financial Crises and Leverage," American Economic Review, Vol. 100, No. 5, pp. 1941-66.

Neely, C.J., 1999, "An Introduction to Capital Controls," Federal Reserve Bank of St. Louis Review, November/December, pp. 13-30.

Nikolov, K., 2011, "Is Private Leverage Excessive?," (mimeo, European Central Bank).

Obstfeld, M., 1994, "The Logic of Currency Crises," Cahiers Economiques et Monetaires, Banque de France, Vol. 43, pp. 189-13.

Obstfeld, M., and A.M. Taylor, 2003, "Globalization and Capital Markets," in Globalization in Historical Perspective, ed. by M.D. Bordo, A.M. Taylor, and J.G. Williamson (Chicago: University of Chicago Press), pp. 121-90.

Ostry, J.D., and others 2011, "Managing Capital Inflows: What Tools to Use?," IMF Staff Discussion Note 11-06.

Perotti, E., and J. Suarez, 2011, "A Pigovian Approach to Liquidity Regulation," International Journal of Central Banking, forthcoming. 
Reinhart, C.M., and K.S. Rogoff, 2009, This Time is Different: Eight Centuries of Financial Folly (Princeton: Princeton University Press).

Schneider, M., and A. Tornell, 2004, "Balance Sheet Effects, Bailout Guarantees and Financial Crises," Review of Economic Studies, Vol. 71, No. 3, pp. 883-13.

Steiner, A., 2011, "Reserve Accumulation and Financial Risk: From Individual Protection to Systemic Risk," (mimeo, University of Osnabrueck).

Stiglitz, J.E., 1982, "The Inefficiency of the Stock Market Equilibrium," Review of Economic Studies, Vol. 49, No. 2, pp. 241-61.

Tirole, J., 2003, "Inefficient Foreign Borrowing: A Dual- and Common-Agency Perspective," American Economic Review, Vol. 93, No. 5, pp. 1678-702.

Tobin, J., 1978, “A Proposal for International Monetary Reform," Eastern Economic Journal, Vol. 4, No. 3-4, pp. 153-9.

Townsend, R.M., 1979, "Optimal Contracts and Competitive Markets with Costly State Verification," Journal of Economic Theory, Vol. 21, No. 2, pp. 265-93.

Végh, C., 2012, Open Economy Macroeconomics in Developing Countries (Cambridge, MA: MIT Press).

Weitzman, M.L., 1974, "Prices vs. quantities," Review of Economic Studies, Vol. 41, No. 4, pp. 477-91. 